\title{
'When we are tired we shall rest': bus boycotts in the United States of America and South Africa and prospects for comparative history
}

\author{
Derek Charles Catsam
}

\begin{abstract}
This article looks at some of the practical, methodological, and disciplinary issues connected to comparative and transnational history through the lens of bus boycotts in South Africa and the United States in the 1950s. Comparative history by its very nature requires historians to transcend both the restrictive boundaries that the profession sometimes imposes as well as a fundamentally interdisciplinary approach to scholarship. Yet as the suggestive comparisons between boycotts in Montgomery, Alabama, Baton Rouge, Louisiana, and the Transvaal in the mid-1950s show, such work can be rewarding in providing a transnational framework for understanding protest movements that transcend national borders. Catsam argues in the end of his article that "a deeper understanding of both [the American and South African] struggles together may well help us better to grasp the significance of each separately."
\end{abstract}

Keywords: protests, boycotts, civil rights, anti-apartheid, Alexandra, Montgomery, Baton Rouge, Martin Luther King, Jr., comparative history, historiography, Witwatersrand.

Disciplines: History, American Studies, African Studies, Politics, Sociology, Black/African American Studies, International Studies, Comparative Studies

\section{Introduction}

In early January 1957 South Africa's Public Utility Transport Corporation (PUTCO) announced that it would be raising bus fares by one penny, from $4 \mathrm{~d}$ to $5 \mathrm{~d}$. This would be the first fare increase on PUTCO buses in twenty years, spokesmen for the parastatal

- Derek Catsam is an assistant professor in the Department of History at the University of Texas of the Permian Basin. He is also the writer and blogger on South African issues for the Foreign Policy Association, based in New York. He is working on a book on bus boycotts in the United States and South Africa in the 1940s and 1950s. 
organization announced, and was largely the result of rising petroleum costs. The fare hike would take place effective on the $7^{\text {th }}$ of January, a Monday. ${ }^{1}$

In response, more than 2000 black South Africans in the northern Johannesburg township of Alexandra met under the leadership of the Alexandra People's Transport Committee (APTC) and voted to commence a boycott of PUTCO. That Monday, thousands heeded the boycott, with APTC estimating that more than 5,000 walked the nineplus miles into Johannesburg, the main center of employment opportunities for township dwellers. Residents of Sophiatown also boycotted PUTCO services, as did blacks in Lady Selborne, a Pretoria township where fares had also increased. PUTCO officials estimated that Monday ridership was down to $2 \%$ of its normal levels, and by the $8^{\text {th }}$, the boycott was total, with no black riders in Alexandra. ${ }^{2}$ The rallying cry for the boycotters was "Azikwelwa!" which in Zulu means "We will not ride!" and which, in a nod to history, was itself borrowed from bus protest campaigns of the $1940 \mathrm{~s}^{3}$

What followed would be a three-month standoff between PUTCO, government officials, and an increasingly emboldened protest movement.

Thirteen months before the commencement of the Alexandra boycott Rosa Parks, a stalwart of Montgomery, Alabama's civil rights struggle, long-time NAACP activist, and respected community member, refused to give up her seat when the bus driver told her to do so. According to Montgomery's segregation laws, Parks' refusal to yield made her subject to arrest, and so the bus driver contacted police, who carted Parks to jail.

On 5 December Parks was convicted of violating Montgomery Jim Crow laws and Montgomery's black population engaged in a one-day bus boycott that proved to be a rousing success. Montgomery's African

1 Rand Daily Mail, 5 January 1957. (Much of the newspaper research for this paper comes from the clippings files at the Historical Collections, William Cullen Library, University of the Witwatersrand.) There is some dispute as to the necessity of the fare hikes. There can be no doubt that PUTCO's costs had risen and profits were down. Nonetheless, protest leader Dan Mokonyone has written that PUTCO 'shed crocodile tears about its meager profits' and that in any case, if Putco can only worry about profits they are better off than we who cannot even manage to make ends meet'. D Mokonyane, Lessons of Azikwelwa: The Bus Boycott in South Africa (Nakong Ya Rena, London, 1994), p. 32.

2 Star (Johannesburg), Rand Daily Mail, Pretoria News, Cape Argus 7 \& 8 January, 1957, Sunday Times, (Johannesburg) 8 January, 1957.

3 Mokonyane, Lessons of Azikwelwa: The Bus Boycott in South Africa, p. 4. 
American community decided to continue with the boycott. ${ }^{4}$

What followed would be a thirteen-month standoff between Montgomery's City Bus Lines, local officials, and an increasingly emboldened protest movement.

The comparisons between the Montgomery and Alexandra bus boycotts, and indeed many of those in both the United States and South Africa, seem obvious at first, and some of the parallels are striking. Both movements saw the emergence of what appeared to be an almost ad hoc mass protest based upon principles of nonviolence in the wake of what had become an intolerable situation, often characterized by abuse, violence, terrorism, and mistreatment. In both cases women took lead roles in organizing and sustaining the boycotts. An impressive array of informal transportation networks emerged in both instances, including shuttle services, carpools and taxis. Masses simply compensated for the buses being off limits by traveling on foot or bicycle. Police and other authorities resorted to intimidation, duplicity and violence. There were disagreements of tactics within each movement. The boycotts also proved to be a source of charismatic leadership, though this was more pronounced in the American case, where Martin Luther King Jr. ascended to what would become his truncated run as the most visible and significant civil rights leader in America and arguably the best-known symbol for freedom and human rights in the world.

These points of symmetry and confluence are significant and worthy of exploration in much further depth. ${ }^{5}$ But equally important are the differences in context, history, and circumstances that make for a vital element of comparative and transnational history. This brief paper will provide tentative suggestions for comparative scholarship between these movements in the United States and South Africa, emphasizing points of contrast as well as briefly touching upon conjunctions.

\section{Comparative history: historiography, methodology and interdisciplinarity}

In recent years, comparative and transnational history has become one of the most exciting trends and vibrant areas for scholarship. And

4 See Stewart Burns' skillfully edited document collection, Daybreak of Freedom: the Montgomery Bus Boycott (Chapel Hill: University of North Carolina Press, 1997).

5 This article marks the beginning, the first steps, of what will be a comprehensive comparative study of these cases. 
no two nodes of comparison have produced as much high quality work as the United States and South Africa on the issue of race. ${ }^{6}$ In 1981 George Fredrickson published White Supremacy: A Comparative Study in American \& South African History, which did not invent comparative history, but pretty clearly redefined the endeavor in almost revolutionary ways. ${ }^{7}$

Fredrickson looms so large, in fact, that non-specialists can be forgiven for forgetting that White Supremacy, which seems to stand alone now, actually had some formidable competition in John W Cell's The Highest Stage of White Supremacy, an equally ambitious treatment of, as Cell's subtitle explicates, "the origins of segregation in South Africa and the American South" and, to a somewhat lesser degree, Stanley Greenberg's Race and State in Capitalist Development: Comparative Perspectives. ${ }^{8}$ Both are fine works, but neither author sustained his inquiries as Fredrickson did in the years and decades to come.

In the quarter century that followed, Fredrickson, who to that point was a respected expert on racial ideologies in the United States, became most well known for his comparative work. He and the field of comparative history became inextricably linked. After what seemed like an interminable delay for his devotees, Fredrickson released the sequel to White Supremacy, Black Liberation: A Comparative History of Black ideologies in the United States and South Africa in 1995. ${ }^{9}$ Other Imagination: George Fredrickson and New Directions in Comparative and Transnational History," in Safundi: The Journal of South African and American Studies, Special issue devoted to George Fredrickson, Issue 21, January 2006. The other articles in the issue are also tremendously useful in situating Fredrickson's work within the literature. African History (Oxford \& New York: Oxford University Press, 1981).

JW Cell, The highest state of white supremacy: the origins of segregation in South Africa and the American South (Cambridge University Press, Cambridge \& New York, 1982) and S Greenberg, Race and state in capitalist development: comparative perspectives (Yale University Press, New Haven,1980). United States and South Africa (Oxford University Press, Oxford and New York, 1995). 
vital works followed. ${ }^{10}$

Fredrickson thus was an essential figure in not only the emerging comparative scholarship that would emerge in the wake of White Supremacy, he also has cast a significant shadow on some of the most vibrant trends in recent scholarship, including transnational studies and even a particular strand of works on diplomatic and international history. The remainder of this section will investigate (admittedly only partially and suggestively, and not comprehensively and exhaustively) some of these trends.

Fredrickson is most closely linked to that work that is explicitly comparative, and in which the nodes of comparison are the United States and South Africa. Fredrickson has endorsed comparison on a grand scale, emphasizing broad geographic terrain, extended time periods, and ambitious phenomena (white supremacy; black liberation, racism - no micro-histories in that lot). There are two especially noteworthy recent trends that have emerged in the comparative historiography involving the United States and South Africa. One buttresses Fredrickson's grand approach, the other goes in the other direction. Fredrickson's imprint nonetheless looms large with both approaches.

The first of these trends has involved branching beyond the United States-South Africa axis to include a third node of comparison. Potentially unwieldy, there have nonetheless been some signs that this is a fruitful, if daunting, approach. In 1992 Donald Harmon Akenson published God's Peoples: Covenant and Land in South Africa, Israel and Ulster (a book, incidentally, reviewed by John Cell in the American Historical Review). Although it does not involve the United States, Akenson's ambitious work reveals one of the possibilities for multi-nation comparisons that Americanists and South Africanists are beginning to take seriously - expanding the nodes of comparison but limiting the thematic acreage. Akenson emphasizes the role of covenant theology, the belief of a people that their tie to a land and thus their dominance over it is ordained by a higher power. Akenson tends to focus on each case individually rather than embrace the sort of full-fledged comparison that Fredrickson has endorsed, and some of his conclusions are problematic (he veers toward a somewhat exceptionalist view of his three societies) but God's People nonetheless kicked off a process that would reach further fruition in scholarship

10 See GM Fredrickson, The comparative imagination: on the history of racism, nationalism, and social movements (Berkeley: University of California Press, 1997). GM Fredrickson, Racism: a short history (Princeton University Press, Princeton, 2003). 
as the last century came to its conclusion. ${ }^{11}$

Anthony W. Marx's 1998 book, Making Race and Nation: A Comparison of the United States, South Africa and Brazil marks, for the time being, the apogee of such multinational studies. Unlike Akenson, Marx covers almost as ambitious thematic territory as Fredrickson has tackled by linking the creation of nations with the simultaneous construction of racial identity so that the two are inextricably bound even as they manifested themselves somewhat differently in the three cases. Marx reveals the particular benefits to adding a third area of analysis in his use of Brazil, for as he ably shows, Brazil lacked the sort of black political mobilization and thus explicitly racialist mobilization among whites that emerged in the United States and South Africa, and as a consequence national identity emerged in some ways more easily in Brazil, where elites effectively skirted the race question that scarred elsewhere. ${ }^{12}$

Brazil represented the third node of comparison as well for a collection of essays for which Fredrickson provided the lead essay, Beyond Racism: Race and Inequality in Brazil, South Africa and the United States. Uneven in quality and approach, Beyond Racism is nonetheless indicative of future directions in comparative studies. ${ }^{13}$ In such endeavors, collaborations such as edited collections will always be a useful way to approach comparative studies because of the difficulties and limitations inherent in comparative work. It will always be more manageable, even if the end results is not more satisfying, for several contributors to wrestle with an aspect of a problem than for one ambitious scholar to do so.

11 DH Akenson, God's peoples: covenant and land in South Africa, Israel and Ulster (Cornell University Press, Ithaca, 1992); JD Cell, Review in The American Historical Review Vol. 98(5), December 1993, pp. 1567-1568.

12 AW Marx, Making race and nation: a comparison of the United States, South Africa and Brazil, (Cambridge University Press, Cambridge and New York, 1998); Incidentally, Yale University's Courtney Young assesses Making race and nation: the comparative imagination and Ran Greenstein's important edited collection, Comparative perspectives on South Africa in a review essay in African Studies Review Vol. 42(3), (December 1999) pp. 56-62.

13 CV Hamilton, et. al., Beyond racism: race and inequality in Brazil, South Africa and the United States (Lynne Rienner Publishers, Boulder \& London, 2001). One other edited collection worth noting in this context is Peter Alexander and Rick Halpern, Racializing class classifying race: labour and difference in Britain, the USA and Africa (Palgrave McMillan, New York, 2000). This book both expands the frame of reference for comparison by focusing on Britain, the United States and the whole of Africa while at the same time limiting focus to questions related to race and labour. Interested readers can see my May $2001 \mathrm{H}$-SAfrica review of this book at http:// www.h-net.msu.edu/reviews/showrev.cgi?path=31222988823518 
Comparative works of the other sort, perhaps best termed as microcomparisons, have not yet hit full stride and yet would seem to reveal the capacity for richness and depth that the more broadly focused studies of necessity must sacrifice. ${ }^{14}$ Whether in the forms of monographs yet to emerge or essays in the respected US-South African studies journal Safundi (including the two books that Safundi has published) and elsewhere, the hope remains that studies centered on specific themes will emerge to fill in gaps of our comparative understanding. ${ }^{15}$ The best book-length study to date is probably James Campbell's Songs of Zion: The African Methodist Episcopal Church in the United States and South Africa, a sensitive and meticulously researched work that has increased our understanding of religious development and identity in the United States and South Africa. ${ }^{16}$ Campbell's book is a work of comparative history that also fits into the next category under discussion, transnational history, where some of the most vibrant work in contemporary scholarship is emerging.

In recent years there has also been an explosion of work not explicitly comparative, but rather that explores the interactions between peoples and institutions in the United States and South Africa, or between Americans and Africans. Furthermore, although one needs not look far to find lamentations about the decrepit state of diplomatic history, which in many university history departments has fallen out of favour, there is one noteworthy exception to this apparent trend: Studies of American relations with Africa appear to be alive and well.

Americans and South Africans have long been fascinated with one another and have found points of comparison and contrast. In some ways, the written legacies of these sojourners mark early examples of transnational scholarship, for even when the goal is comparative reflection, the project is the result of the sorts of interaction on the ground that transnational scholars have come to excel at producing. Maurice Evans, a white South African, was one of the first South

14 It is into this trend where I hope my bus boycott project will fit.

15 See A Offenburger and C Saunders, (Eds.), A South African and American comparative reader: the best of Safundi and other selected articles (Safundi, 2003); and A Offenburger, C Saunders, and C Lee, (Eds.) Safundi: South Africa \& The United States compared: the best of Safundi, 2003-2004 (Safundi: 2005). Along these lines, in 1996 the University of London's School of Advanced Study, Institute of Commonwealth Studies held a conference, "Beyond white supremacy: towards a new agenda for the comparative histories of South Africa and the United States" for which Fredrickson was the keynote speaker. The collection was gathered in the Institute's "Collected seminar papers 49."

16 J Campbell, Songs of Zion: The African Methodist Episcopal Church in the United States and South Africa (University of North Carolina Press, Chapel Hill, 1998). Campbell contributed to the conference discussed in footnote 12 , above. 
Africans to leave such a record, and his book, Black and White in the Southern States: A Study of the Race Problem in the United States from a South African Point of View was recently re-issued in the Southern Classics Series of the University of South Carolina Press with the ubiquitous Fredrickson providing an introduction. ${ }^{17}$ Based on his 1914 travels to the South, Evans, one of the English-born South Africans who was present at the birth of the Union of South Africa in 1910, Evans' book brings together his observations about the American racial situation and allows him to draw the conclusion that America was not the place to look to settle South Africa's racial issues, as in the South of necessity blacks and whites lived amongst one another. Evans would conclude from this that strict racial separation was South Africa's only hope.

Of equal historical significance, but without a comparable agenda, is the record that the famed American civil rights activist and 1950 Nobel Peace Prize winner Ralph Bunche left after his three month trip to South Africa from September 1937 to January 1938. Howard University professor Robert Edgar compiled and annotated Bunche's notes and Ohio University Press released them in a 1992 volume, An American in South Africa: The Travel Notes of Ralph J. Bunche 28 September 1937-1 January 1938. ${ }^{18}$

Far from being an anomaly, Bunche's marvelous, insightful account can be seen as simply an early example of American black interest in South Africa's racial problems. One of the most exciting trends in transnational historiography is the explosion in the last decade or so of studies investigating Americans addressing not only South African but African affairs generally. Not necessarily the stuff of traditional diplomatic history (more on which momentarily) these studies investigate the role that African Americans and their white supporters played in drawing attention to not only America's racial problems, but also to those of South Africa, and to pushing an aggressive approach toward combating apartheid.

Perhaps the most prominent and well-regarded early example of such a study is Lewis Baldwin's groundbreaking Toward the Beloved Community: Martin Luther King, Jr. and South Africa which examined American responses to the South African struggle through the most

17 MS Evans, Black and white in the Southern States: a study of the race problem in the United States from a South African point of view with a new introduction by George Fredrickson, (University of South Carolina Press, Columbia, 2001). 
visible civil rights leader. ${ }^{19}$ Baldwin showed how King was at the forefront of an American engagement with South Africa's onerous racial system that would continue to grow to the point of directly affecting American policy in the 1980s.

In a small and sadly overlooked book published in 1999, political scientist Donald Culverson explored American anti-apartheid activism in Contesting Apartheid: U.S. Activism, 1960-1987.20 The topic would receive its fullest treatment to date in Francis Njubi Nesbitt's wonderful book Race for Sanctions: African Americans Against Apartheid, 19461994. ${ }^{21}$ Both Culverson and Nesbitt recognize both the salience that the anti-apartheid struggle held for many Americans, especially blacks dealing with their own issues of racial oppression, and reveal the crossnational implications of their struggle, as well as the difficulties they faced within the United States in mounting a struggle that crossed national boundaries during the Cold War years.

Black Americans did not limit their gaze to South Africa either. American policy toward Africa and the anti-colonial struggle drew the attention of many Americans, and part of this growing transnational trend has been the emergence of a first-rate body of work. The best examples are Brenda Gayle Plummer's Rising Wind: Black Americans and U.S. Foreign Affairs, 1935-1960, Penny von Eschen's Race Against Empire: Black Americans and Anticolonialism, 1937-1957, James Meriwether's Proudly We Can Be Africans: Black Americans and Africa, 1935-1961 and Plummer's edited collection, Windows on Freedom: Race, Civil Rights and Foreign Affairs 1945-1988. ${ }^{22}$

19 L Baldwin, Toward the beloved community: Martin Luther King, Jr. and South Africa (The Pilgrim Press, Cleveland, 1995). Safundi readers may recall a memorable recent exchange that Professor Baldwin and I had in the pages of Safundi (Issues 15, 17 and 18) in which I maintained that Baldwin had overreached in trying to link King's legacy beyond parameters that I felt the historical record could support. Nonetheless, Baldwin's book is an essential contribution to what has become, in no small parts thanks to his work, one of the most exciting subfields in the historical profession.

D Culverson, Contesting Apartheid: U.S. activism, 1960-1987 (Westview Press, Boulder, 1999).

21 F Njubi Nesbitt, Race for sanctions: African Americans against Apartheid, 19461994 (Indiana University Press, Bloomington, 2004). My review of Race for Sanctions appeared in History: Reviews of New Books, Vol. 33(4), Summer 2005

22 BP Plummer, Rising wind: black Americans and U.S. Foreign Affairs, 1935-1960 (University of North Carolina Press, Chapel Hill, 1996); P von Eschen, Race against Empire: black Americans and anticolonialism, 1937-1957 (Cornell University Press, Ithaca, 1997); J Meriwether, Proudly we can be Africans: black Americans and Africa, 1935-1961 (University of North Carolina Press, Chapel Hill, 2002); and Plummer, (Ed.), Windows on freedom: race, civil rights and foreign affairs 19451988 (University of North Carolina Press, Chapel Hill, 2003). It should be noted that Culverson contributes an essay to Plummer's collection. It also is worth recognizing that the University of North Carolina Press has been at the forefront of this sort of transnational scholarship.. 
Though somewhat less transnational in nature, there is also a growing literature on the role that the Cold war played in shaping (and stunting) black aspirations during the civil rights movements. One of the predominant themes of the transnational literature is the way in which politicians manipulated Cold War fears to frustrate the desires of citizens striving for better treatment and equal rights. American civil rights activists, even when they were not agitating for sanctions against apartheid or to push America to recognize African liberation struggles, operated within this environment as well. The best of these works include Mary Dudziak's Cold War Civil Rights: Race and the Image of American Democracy, Thomas Borstelmann's The Cold War and the Color Line: American Race Relations in the Global Arena, George Lewis' The White South and the Red Menace: Segregationists, Anticommunists, and Massive Resistance and Jeff Woods' Black Struggle, Red Scare: Segregation and Anti-Communism in the South, 1948-1968. ${ }^{23}$ Generally, Dudziak's and Borstelmann's books are more concerned with the ways in which race and the Cold War shaped American race relations at home and foreign policy abroad, Woods and Lewis are more concerned with the pas de deux between the Civil Rights Movement and advocates of massive white resistance. All four books are important contributions. At first glance they may not seem to fit into a discussion on comparative and transnational history, but they do inasmuch as international relations and diplomatic history can benefit from an infusion of transnational and comparative perspectives. Much of the transnational literature of the last few years has operated under the understanding that the international context within which actors moved was vital to what they could accomplish.

Writing comparative and transnational history presents a series of problems for historians. In order for comparative history to be truly effective, its practitioners have to develop a deep familiarity over two literatures, a daunting endeavor given that most of us realize that developing mastery in one area is something most of us can only approximate. Because of this task, few advisors encourage their

23 M Dudziak, Cold war civil rights: race and the image of American democracy (Princeton University Press, Princeton, 2000); T Borstelmann, The Cold War and the color line: American race relations in the global arena (Cambridge: Harvard University Press, 2001); G Lewis, The White South and the Red Menace: segregationists, anticommunists, and massive resistance (University Press of Florida Gainesville DATE????) and J Woods, Black Struggle, Red Scare: Segregation and Anti-Communism in the South, 1948-1968 (Louisiana State University Press, Baton Rouge, 2004). For the sake of full disclosure, I attended graduate school with Jeff Woods, we are co-editors on a book project, and I consider him a friend, as I do George Lewis. I do not, however, think that has prejudiced me into my conviction that these are both good and important books. 
students to pursue comparative studies. Few junior scholars feel comfortable working in two or more areas. One of the most serious impediments to comparative scholarship within the profession is the proprietary hold too many historians have over their subfield. The comparativist is familiar with the plight: Show up at a conference of South Africa specialists, and they will look askew, questioning your credentials in South African history. Show up before an audience of Americanists and the problem is the opposite. Apply for a job and all sides will have questions over where your loyalties will lie, as if Africanists and Americanists come from different worlds in which zero sum games prevail. And given the nature of the profession, where resources are scarce and every desired hire meets a fight with administration, zero-sum does too often win out.

Add to these unseemly aspects of interdepartmental struggles the fundamentally interdisciplinary nature of comparative studies and the difficulties multiply. When a historian walks into a room of social scientists, she is likely to hear questions about 'field work' and 'methodology', 'literature reviews' and 'models', terms with which most historians have an at-best distant and sometimes skeptical relationship.

So what is the determined transnationalist to do? One approach is simply to whistle past the graveyard, to ignore the internecine struggles and cross-disciplinary sniping matches. But while in an ideal world the work stands for itself, we all know that academia is rarely an ideal world. The best advice in this context is to approach ones work openly, and not to start off as a comparativist. It might instead be useful for the scholar interested in comparing the United States and South Africa effectively to pursue separate research agendas, to become both a South Africanist and an Americanist. Rather than just attend history conferences, the comparative historian should also attend meetings in political science, sociology, and especially African and American studies meetings where interdisciplinary discussion is not only accepted, but expected. Some of the same askew looks and dubious responses will still emerge, but at a certain point one's work will have to stand on its own merits. Plus, only after earnest immersion within the separate subfields will one truly be qualified for the sort of comparative endeavor that requires a full immersion across subdisciplines and academic fields.

\section{Bus Boycotts in the Witwatersrand: 1944-1957}

During the 1940s rising bus fares in South Africa's Witwatersrand had led to a series of bus boycotts. An increasingly activist and 
conscientized African population used various protests, stay-aways, and boycotts throughout the decade to challenge the tightening noose of segregation, and bus boycotts were among the more prominent frontal challenges. Between 1940 and 1950 there were at least eight documented instances of bus boycotts in South Africa. Seven of them involved fares in whole or in part. Five of these occurred in Alexandra. ${ }^{24}$ Furthermore, an epochal strike by the African Mineworkers Union in 1946 had showed young cadres of Africans the possibilities for mass action while at the same time providing a rude awakening for increasingly concerned white South Africans. With the onset of apartheid after the National Party victory in the 1948 elections, repression became ever more brutal even as Africans called for greater freedoms.

Township residents in 1950 in Evaton, in 1954 in Evaton, Brakpan and Kliptown, in 1955 in Katlegong and Evaton, and in 1956 in Brakpan continued this protest tradition. All of this culminated in the events of 1957 when Africans from Alexandra and nine other areas, many of whom protested in explicit sympathy with Alexandrans, used bus boycotts to protest rapidly rising fares..$^{25}$

Most township residents were at the whim of public transportation companies, as residential segregation policies forced people to live far from their places of employment. Alexandra, for example, was 15 kilometers (9 miles) from Johannesburg. In the Alexandra boycott that ensued in 1957, 60000 commuters boycotted for more than three months with women, who worked as domestics in the city, taking serious leadership roles.

Alfred Nzo and the local branch of the African National Congress (ANC) spearheaded the boycotts largely without the help of the national ANC, which was preoccupied with the Treason Trials. Other organizations and individuals played a significant role as well, and the internal political dynamics associated with the boycott were often intense. The Alexandra bus boycott ended when Johannesburg employers agreed to provide subsidies for their workers and PUTCO agreed to maintain the $4 \mathrm{~d}$ price for any riders who agreed to buy weekly fare coupons that would guarantee regular riders a maintained rate and PUTCO both a more guaranteed cash flow as well as increased fares from irregular riders.

24 S Essig, "Transportation boycotts in South Africa: 1940-1984," South African Institute of Race Relations (Hereafter SAIRR) Topical Paper June 1985, p. 5. In HW Van Der Merwe Papers BC1148, Archives \& Manuscripts, University of Cape Town. S Essig, "Transportation Boycotts in South Africa," p. 5. 


\section{Bus Boycotts in the United States: Baton Rouge and Montgomery}

Meanwhile, in the United States, against a backdrop of both heightened civil rights activity and a rising tide of massive resistance, black Americans in Baton Rouge in 1953, Montgomery in 1955-1956, and Tallahassee in 1956 engaged in their own bus boycotts. ${ }^{26}$ If South Africans protested over fares, blacks in the American South had more diffuse goals that also might initially seem to be of more noble origins than those of the South Africans.

At first glance, black Americans wanted either to end or modify segregation. Most famously, in Montgomery the initial demands that the Montgomery Improvement Association (MIA) presented before local officials, were quite moderate. Although Montgomery's black citizens found segregation loathsome, the initial demands fell short of overhauling the system. Instead MIA demands were threefold:

Rather than having black patron give up their seats to whites when the bus filled, the MIA wanted a flexible line of segregation whereby blacks filled the bus from the back, whites from the front, and when the bus was full, bus drivers would not be able to demand that black patrons stand;

More courteous treatment of black passengers; and

The hiring of black drivers for predominantly black neighborhoods. ${ }^{27}$

It was only after insurmountable official intransigence that the MIA called for nothing short of the end of segregation on the city's buses.

If the Montgomery Bus Boycott began with relatively modest goals, the Baton Rouge boycott, which lasted for nine days in June 1953, had asked for even less in the form of concessions and stemmed initially from the same issues South Africans faced: In the early weeks of 1953 the Baton Rouge City-Parish Council decided to raise fares on city buses. A young pastor, Reverend T J Jemison, went before the council in February 1953 and called for an end to segregation on the city's buses. With little fanfare the local officials did so, abolishing reserved seating as long as African Americans did not sit with or in front of any

26 On the Baton Rouge boycott see Signpost to Freedom: The 1953 Baton Rouge Bus Boycott, Louisiana Public Broadcasting (LPB). On Tallahassee, see GA Rabby, The pain and the promise: the struggle for civil rights in Tallahassee Florida, (University of Georgia Press, Athens, 1999), especially pp. 9-46.

27 Montgomery Advertiser, December 9, 1955; excerpted in Burns, pp. 98-99. 
white passengers. Blacks would continue to board from the back and whites from the front. ${ }^{28}$

The new law was supposed to take effect in mid-March, but for nearly three months bus drivers and their employers ignored the council's action and segregation on buses continued unabated. After a driver violently 'manhandled' a woman who tried to sit in one of the reserved seats for whites in the front section, black Baton Rouge mobilized, with Reverend Jemison in the lead. Negotiations led to a settlement on June 24 in which blacks would load from the back, whites from the front, no black passengers could sit with or in front of whites, and the front seats were reserved for whites, the back bench on the bus for black passengers. ${ }^{29}$ In effect, what began as black complaints over fare raises in conjunction with segregation ended in a nine-day boycott that achieved results similar to the goals the MIA desired as its boycott commenced two-and-a-half-years hence. In Baton Rouge, an increase in fares and the local response served to reveal larger dynamics at work. This is a valuable lesson for understanding the South African context.

\section{The Comparative Lens: Subsistence or Civil Rights?}

The political scientist Tom Lodge has called the bus boycotts in Evaton and Alexandra, which were the largest of their kind, 'the two major subsistence protests of the 1950s', a description that is accurate, but incomplete and misleading. ${ }^{30}$ The proximate cause of the boycotts was the rise in fares. Indeed, one of the phrases that emerged from the boycott in conjunction with "Azikwelwa" was 'Asinamali', which means 'we have no money', and which was intended not as a lamentation but rather as an assertion of defiance, in recognition of how racism and poverty were inextricably linked in the South African context. The boycotts did not attempt to address larger problems in the system that left Africans vulnerable to a penny a day fare increase. But the root cause of the bus boycotts stemmed from the circumstances that created a place like Alexandra to begin with. Africans were

See LPB, Signpost to Freedom: The 1953 Baton Rouge Bus Boycott, Louisiana Public Broadcasting; See also M Price, "Baton Rouge Bus Boycott Background," Louisiana State University Library Special exhibit. Available at http:/ /www.lib.lsu.edu/special/ exhibits/boycott/background.html

See LPB, Signpost to Freedom and Mary Price, "Baton Rouge Bus Boycott Background."

30 T Lodge, Black Politics in South Africa Since 1945, (Longman, London and New York, 1983), p. 153. 
disproportionately (indeed, almost exclusively) concerned with and thus affected by rising fares because Africans were most reliant upon public transportation. The economic sector being what it was in the townships - largely informal, virtually no industry, a small-tononexistent service sector, almost no public sector jobs, and so forth - meant that to find steady employment, Africans had to go to the city, to Johannesburg, in order to work. Because of the host of segregation and later apartheid laws, Africans had no choice but to live in the townships and commute to the cities.

Furthermore, given the political climate and the totalitarian nature of the apartheid state, (which would only get worse in the years to come, especially after Sharpeville in March 1960) protesting against fares was a proxy for protesting against apartheid. The buses were a tangible manifestation of a holistically closed society. Boycotting rising fares was tantamount to challenging apartheid, even if the leaders of the boycott movements knew that to assert as much meant to violate a host of laws that could lead to imprisonment and worse. The 1957 boycotts took place within the context of the Treason Trials against the leaders of the Freedom Charter Movement of the African National Congress, after all. Punishment for political activism was thus not an abstraction for boycott participants.

As one contemporary of the boycotters wrote in 1958:

\begin{abstract}
The people of the 'dark City' of Alexandra, an unusually stubborn and independent suburb of a hundred thousand Africans lying just outside the municipality, were united in their dislike for the smoky green buses called tigers. The long queues waiting without shelters, sometimes for an hour and a half in the early mornings, the rude and autocratic officials, and the cramped uncomfortable journey, stood for everything that was most hated about the white men's city to which the buses carried tens of thousands of workers every day. The extra-penny touched off all this latent hatred. ${ }^{31}$
\end{abstract}

Challenging bus fares thus was a challenge to apartheid in one of the only ways that might have been able to prove effective under the circumstances.

\title{
Conclusion
}

In the middle of the Alexandra bus boycott, Dan Mokonyane, assistant secretary of the APTC and a law student at the University of the Witwatersrand, joined several of his more radical Africanist colleagues

31 A Terrels Sampson, The Treason Cage, (Heinemann, Portsmouth, 1958) pp. 207208; quoted in Mokonyane, Lessons of Azikwelwa, p. 4. 
in calling for transforming the boycott into a general strike. At a mass meeting Mokonyane declared:

When we are tired we shall rest... They are punishing us because we are poor. ${ }^{32}$

In Montgomery, meanwhile, there is the famous story of old Mother Pollard, as she was known far and wide. When offered a ride during the boycott and told that everyone would understand if she chose to ride the buses, Mother Pollard famously responded:

My soul is tired but my feets is rested.

In both South Africa and the United States in the 1950s tired feet and rested souls embraced the principles behind 'Azikwelwa' and 'Asinamali'. The circumstances and contexts were different, but the universality of the desire for human rights marched on in the obstinate face of oppression. Feet spoke eloquently as the poor walked on, taking dignity where it had been stolen and demanding justice where it was absent. A deeper understanding of both struggles together may well help us better to grasp the significance of each separately. 